\title{
MANAJEMEN SUMBER DAYA MANUSIA DI LEMBAGA SINERGI FOUNDATION
}

\author{
Oleh: \\ Emma Rachmawati Pratami, Rudi S. Darwis, \& Nandang Mulyana \\ Email: \\ pratamiemma@gmail.com
}

\begin{abstract}
ABSTRAK, Kehadiran lembaga-lembaga pelayanan sosial di Indonesia membantu masyarakat dalam memperoleh layanan sosial yang tidak disediakan oleh pemerintah. Lembaga pelayanan sosial membantu menyediakan akses dan sumber-sumber untuk memenuhi kebutuhan masyarakat. Suatu lembaga tidak terlepas dari komponen-komponen penyusunnya. Lembaga memiliki visi-misi, tujuan lembaga didirikan, program-program, struktur organisasi, pengelolaan dana, dan manajemen kelembagaan. Atau dapat disebut komponen internal dan eksternal yang membangun lembaga. Begitupun dengan faktor-faktor dari luar seperti aturan hukum dan kondisi sosial-politik yang turut mempengaruhi. Hal yang mendasar dari berjalannya suatu lembaga terletak pada sumber daya manusianya. Apabila SDM yang dimiliki berkualitas dan berkompeten, akan membawa kemajuan pada lembaga begitupun sebaliknya. Walaupun memiliki visi-misi yang bagus tetapi apabila SDM kurang handal maka lembaga tersebut sulit mengalami kemajuan. Diperlukan pengelolaan SDM yang baik agar SDM dapat menjadi aset untuk memajukan lembaga.
\end{abstract}

Kata kunci: lembaga pelayanan sosial, sumber daya manusia, manajemen SDM

\section{HUMAN RESOURCE MANAGEMENT IN SINERGI FOUNDATION ORGANIZATION}

ABSTRACT, The presence of social service agencies in Indonesia assist the public in obtaining social services not provided by the government. Social service agencies to help provide access and resources to meet the needs of the community. An institution can not be separated from its components. Institutions have the vision, mission, objectives established institutions, programs, organizational structure, fund management and institutional management. Or can be called internal and external components to build institutions. As well as with external factors such as the rule of law and socio-political conditions that influence. The fundamental thing of the passage of an institution lies in its human resources. If the quality of human resources and competent, will bring progress on the institution and vice versa. Although it has a great vision and mission but if HR is less reliable then the institution is difficult to progress. Good HR management is required in order HR can be an asset to promote the institution.

Key words: social service organization, human resource, human resource management

\section{PENDAHULUAN}

Kebutuhan manusia tidak terbatas. Ketika kebutuhan tersebut sulit untuk dipenuhi serta pemerintah pun terbatas dalam menyediakan pelayanan-pelayanan. Maka hadirlah lembaga independen yang dibentuk oleh masyarakat 
untuk membantu memenuhi kebutuhan manusia, terutama di bidang pelayanan sosial.

Lembaga pelayanan sosial memiliki fungsi utama menyelenggarakan pelayanan kesejahteraan sosial yang ditujukan untuk memecahkan masalah dan atau memenuhi kebutuhan masyarakat (B. Wibhawa, 2010: 84).

Salah satu lembaga pelayanan sosial yang akan menjadi subyek penelitian penulis adalah Sinergi Foundation yang berlokasi di Bandung. Sinergi Foundation merupakan lembaga independen milik publik yang berupaya mendorong serta membangun kolaborasi menuju masyarakat yang mandiri, produktif, dan berkarakter. Lembaga ini fokus pada bidang pendidikan, pemberdayaan ekonomi, kesehatan, pembangunan sosial, dan bisnis sosial. Masing-masing bidang memiliki beberapa program dengan sasaran masyarakat sebagai penerima manfaat.

Suatu lembaga tidak terlepas dari pengelolaan komponen internal dan eksternalnya, yang dapat dijadikan sebagai alat dalam menentukan rencana strategis lembaga tersebut. Salah satu komponen internal yang dimiliki yaitu sumber daya manusia. Sumber daya manusia yang berkualitas akan menentukan pencapaian tujuan dari lembaga, maka bagaimana lembaga dapat mengelola dan memanfaatkan sumber daya manusia secara optimal. Seperti dikemukakan oleh Rex A. Skidmore (1995:229), Staffing is a major administrative process that involves obstaining staff, maintaining, and working with staff members, and terminating their positions when necessary.

Salah satu metode Pekerjaan Sosial yaitu Administrasi Pekerjaan Sosial yang merupakan proses mentransformasi sumbersumber masyarakat (manusia dan finansial) ke dalam program pelayanan masyarakat. Untuk melihat apakah sumber daya manusia akan menjadi kekuatan atau kelemahan dari lembaga tersebut.
Berdasarkan latar belakang tersebut, maka peneliti ingin mempelajari komponen sumber daya manusia serta pengelolaannya dalam memberikan pelayanan sosial yang dilakukan oleh Lembaga Sinergi Foundation di Bandung, yang terangkum dalam skripsi berjudul: "Manajemen Sumber Daya Manusia pada Lembaga Sinergi Foundation Bandung”.

\section{TINJAUAN PUSTAKA}

Dalam memberikan pelayanan sosial, ada yang secara langsung maupun tidak langsung. Secara langsung dapat melalui badan-badan atau organisasi tertentu yang bergerak di bidang pemberian bantuan sosial secara profesional. Sementara tidak langsung melalui perumusan kebijakan sosial di tataran pemerintahan.

Organisasi yang memberikan pemberian bantuan sosial secara langsung biasa disebut Organisasi atau Lembaga Pelayanan Sosial. Seperti menurut Budhi Wibhawa (2010: 84), bahwa lembaga pelayanan sosial memiliki fungsi utama menyelenggarakan pelayanan kesejahteraan sosial yang ditujukan untuk memecahkan masalah dan atau memenuhi kebutuhan masyarakat.

Adapun karakteristik dari organisasi pelayanan sosial dikemukakan oleh Martin (dalam B. Wibhawa, 2010:120), diantaranya:

- Organisasi pelayanan sosial didasarkan pada nilai-nilai yang diterima oleh semua atau sebagian penting anggota masyarakat dimana mereka beroperasi.

- Organisasi pelayanan sosial memiliki tanggung jawab untuk melindungi dan mendukung kesejahteraan baik kepada pengguna jasa langsung dan masyarakat pada umumnya.

- Organisasi pelayanan sosial memperoleh kewenangan dan sumber oleh semua atau sebagian penting masyarakat umum, yaitu sumber-sumber dan donasi menurut undang-undang dan bergerak tanpa tujuan mencari keuntungan. 
Organisasi pelayanan sosial berbentuk organisasi sehingga memiliki komponen internal dan eksternal itu sendiri.

Menurut Kettner (2002:71) terdapat 6 komponen internal dalam lingkungan organisasi, yaitu:

\section{Visi, Misi, dan Filosofi Organisasi}

Visi merupakan suatu pernyataan ringkas tentang cita-cita organisasi yang berisikan arahan yang jelas dan apa yang akan diperbuat oleh organisasi di masa yang akan datang.

Kemudian misi merupakan penetapan tujuan dan sasaran yang mencakup kegiatan jangka panjang tertentu dan jangka pendek yang akan dilakukan dalam upaya mencapai visi yang telah ditetapkan. Serta filosofi berisikan tata nilai yang menggerakkan nurani manusia yang terlibat dalam organisasi untuk memiliki kesamaan visi.

\section{Perencanaan Organisasi}

Perencanaan terdiri dari 3 level:

1) Perencanaan Strategis berusaha menggunakan data yang tersedia untuk kebutuhan proyek masa depan dan sumber daya dan menciptakan proses yang berorientasi maju.

2) Perencanaan Jangka Panjang melibatkan pemeriksaan tindakan yang dibutuhkan untuk mencapai ekspektasi yang spesifik dalam perencanaan strategis.

3) Perencanaan Operasional diterjemahkan sebagai jangka layanan manusia, atau perencanaan program. Perencanaan program melibatkan analisis dari masalah sosial atau masyarakat dan detail rencana dari semua elemen dalam program.

3. Operasional Organisasi memerlukan pandangan regular dan pemeriksaan program dan layanan yang ditawarkan sebagai fungsi semua dukungan. Pandangan operasi program mungkin memeriksa beberapa faktor sebagai pencapaian program dalam hubungan pada objektivitas program, kecukupan data, pelaporan dan sistem evaluasi, atau efisien digunakan untuk mendukung staff.

Sumber Daya Manusia menunjuk pada berbagai fungsi yang melibatkan supervisi dan manajemen dari staff dan relawan. Proses perencanaan sumber daya manusia dimulai dari menguji operasi organisasi dan menentukan fungsi pekerjaan yang dibutuhkan untuk menyelesaikan tujuan program dan objektif.

4. Sumber Daya Teknologi mencakup perlengkapan dan keahlian untuk melaksanakan aktivitas pekerjaanpekerjaan profesional dan teknis bekerja dari organisasi.

5. Sumber Daya Keuangan menentukan darimana pendanaan berasal. Mencakup sumber, jumlah, pengalokasian, dan keberlangsungan ketersediaan dana.

Dari ke enam komponen tersebut, penulis bermaksud mengupas salah satu komponen yang sangat berpengaruh terhadap kelangsungan organisasi, yaitu Sumber Daya Manusia.

Kondisi saat ini persaingan begitu ketat sehingga hanya pribadi yang unggullah yang dapat memenangkan kompetisi. Sumber daya manusia (SDM) dituntut untuk terus-menerus mampu mengembangkan diri secara aktif. SDM harus menjadi manusia yang mau belajar dan bekerja keras sehingga potensinya berkembang maksimal. Apabila SDM tidak siap menghadapi tantangan dan perubahan yang terjadi di lingkungannya, ini akan menjadi ancaman karena tidak dapat bersaing dalam kehidupan.

SDM yang tidak memiliki kesanggupan menghadapi tuntutan-tuntutan globalisasi menganggap pekerjaan sebagai beban. Sehingga menyebabkan etos kerja yang rendah.

Untuk menjawab tantangan tersebut harus disiapkan tenaga kerja yang andal di berbagai bidang masing-masing. Pembentukan SDM 
yang andal dalam organisasi dimulai sejak proses seleksi sampai mengevaluasi kinerja pekerjaan yang telah dilakukan. Menurut E. Sutrisno (2009:2) mengemukakan bahwa,

"Sumber daya manusia merupakan satusatunya sumber daya yang memiliki akal perasaan, keinginan, keterampilan, pengetahuan, dorongan, daya, dan karya (rasio, rasa, dan karsa). Semua potensi SDM tersebut berpengaruh terhadap upaya organisasi dalam mencapi tujuan. Betapapun majunya teknologi, perkembangan informasi, tersedianya modal dan memadainya bahan, jika tanpa SDM sulit bagi organisasi itu untuk mencapai tujuannya".

Pada dasarnya, SDM adalah suatu sumber daya yang sangat dibutuhkan oleh organisasi. Sebab, sumber daya manusia adalah sumber yang berperan aktif terhadap jalannya suatu organisasi dan proses pengambilan suatu keputusan.

SDM yang berkualitas tinggi menurut Ndraha (dalam E. Sutrisno, 2009:4) adalah sumber daya manusia yang mampu menciptakan bukan saja nilai komparatif tetapi juga nilai kompetitif-generatif-inovatif dengan menggunakan energi tertinggi seperti: intelligence, creativity, dan imagination; tidak lagi semata-mata menggunakan energi kasar, seperti bahan mentah, lahan, air, tenaga, otot, dan sebagainya.

Melihat begitu berperannya dalam organisasi maka SDM perlu dikelola secara handal untuk memaksimalkan potensinya yang berujung pada tercapainya tujuan dari organisasi tersebut.

Saat ini telah dikenal suatu konsep mengenai pengelolaan SDM yang bernama Manajemen Sumber Daya Manusia (MSDM). Menurut E. Sutrisno MSDM sebagai suatu perencanaan, pengorganisasian, pengarahan, dan pengawasan atas pengadaan, pengembangan, kompensasi, pengintegrasian, pemeliharaan, dan pemutusan hubungan kerja dengan maksud untuk mencapai tujuan organisasi secara terpadu.
Tujuan MSDM menurut Cushway (dalam Irianto, 2001) meliputi:

1. Memberi pertimbangan manajemen dalam membuat kebijakan SDM untuk memastikan bahwa organisasi memiliki pekerja yang selalu siap mengatasi perubahan dan memenuhi kewajiban pekerjaan secara legal.

2. Mengimplementasikan dan menjaga semua kebijakan dan prosedur SDM yang memungkinkan organisasi mampu mencapai tujuannya.

3. Menangani berbagai krisis dan situasi sulit dalam hubungan antar pekerja untuk meyakinkan bahwa mereka tidak menghambat organisasi dalam mencapai tujuannya.

4. Menyediakan media komunikasi antara pekerja dan manajemen organisasi.

Sementara itu, menurut Schuler (dalam Irianto, 2001), setidaknya MSDM memiliki tiga tujuan utama, yaitu:

1. Memperbaiki tingkat produktivitas.

2. Memperbaiki kualitas kehidupan kerja.

3. Meyakinkan organisasi telah memenuhi aspek-aspek legal.

Pengelolaan yang memberikan kesempatan kepada SDM untuk berperan aktif dalam organisasi bertujuan agar pekerjaan menjadi lebih menarik sehingga mampu mendorong semangat kerja SDM dan memotivasi mereka untuk melakukan yang terbaik dalam pekerjaannya.

Seperti diketahui bahwa fungsi MSDM salah satunya berbicara tentang masalah staffing dalam organisasi, yang mencakup analisis tugas/jabatan, rekrutmen, dan seleksi calon tenaga kerja, orientasi, pelatihan, pemberian upah, penilaian, dan pengembangan SDM. Karena aspek SDM begitu strategis, maka MSDM melibatkan faktor-faktor lingkungan internal organisasi (strength and 
weakness) serta lingkungan eksternal (opportunity and threat). Sehingga kegiatan pengembangan SDM digunakan untuk merespon perubahan-perubahan eksternal agar faktor-faktor lingkungan internal organisasi menjadi kuat dan kompetitif (Yuniarsih, 2013: 8).

Jeffrey Pfeffer (dalam Irianto, 2009) berargumentasi bahwa sumber daya manusia merupakan sumber keunggulan daya saing yang mampu menghadapi berbagai tantangan. Tidak seperti teknologi yang dapat berkurang keampuhannya.

Di sisi lain, SDM dapat tetap bertahan karena memiliki kompetensi manajerial, yaitu kemampuan untuk merumuskan visi dan strategi organisasi serta kemampuan untuk memperoleh dan mengarahkan sumbersumber daya lain dalam rangka mewujudkan visi dan menerapkan strategi organisasi.

Dalam rangka operasional, kompetensi tersebut membuat SDM mampu menggali potensi sumber-sumber daya lain yang dimiliki organisasi, mampu mengefektifkan dan mengefisiensikan proses dalam organisasi serta mampu menghasilkan pelayanan yang membantu akses dan kebutuhan masyarakat. Hal tersebut akan memberikan pengaruh positif bagi organisasi.

Dalam penelitian ini penulis melihat isu penelitian melalui perspektif Administrasi Pekerjaan Sosial. Kidneigh (dalam B. Wibhawa, 2010) berpendapat bahwa administrasi pekerjaan sosial adalah "proses transformasi kebijakan sosial ke dalam pelayanan-pelayanan sosial...melalui proses dua cara:

(1)...transformasi kebijakan ke dalam pelayanan-pelayanan sosial konkrit (nyata), dan (2) menggunakan pengalaman dengan merekomendasikan modifikasi kebijakan".

Keterkaitan dengan MSDM bahwa dalam organisasi pelayanan sosial terdapat komponen yang begitu berpengaruh terhadap berjalannya organisasi. Untuk menjalankan organisasi diperlukan kemampuan administrator dalam membuat kebijakan yang menghasilkan tugastugas yang akan diselesaikan oleh SDM yang dimiliki oleh organisasi tersebut.

Oleh karena itu SDM memiliki peranan dan pengaruh terhadap berjalannya suatu organisasi.

\section{DAFTAR PUSTAKA}

Kettner, Peter M. 2002. Human Service Organizations. USA: Allyn \& Bacon.

Skidmore, Rex A. 1995. Social Work Administration. USA: Allyn \& Bacon.

Sutrisno, Edy. 2009. Manajemen Sumber Daya Manusia. Jakarta: Kencana.

Wibhawa, B. dan Santoso, T.R. 2010. Dasardasar Pekerjaan Sosial. Bandung: Widya Padjadjaran.

Yuniarsih, T. \& Suwatno, 2013. Manajemen Sumber Daya Manusia. Bandung: Alfabeta. 